\title{
Prostatakreft -
}

\section{behandlingsutfall og bivirkninger}

\section{Fire av fem som får fjernet prostata er impotente ett år etter opera- sjonen. Risikoen for ufullstendig fjerning av svulstvev er mindre når kirurgen utfører mange operasjoner årlig.}

Prostatakreft uten spredning behandles med operasjon (radikal prostatektomi) eller strålebehandling. Aktiv overvåking kan gi bedre livskvalitet, men det kan være vanskelig å avgjøre hva som er rett behandling for den enkelte.

- Operasjon og strålebehandling gir en del bivirkninger, som impotens, urinlekkasje og tarmproblemer. Det er også en risiko for at ikke alt svulstvevet blir fjernet, sier Anders Svaboe Steinsvik.

Steinsvik har undersøkt risiko for bivirkninger og risiko for at det er svulstvev igjen etter operasjonen hos 703 menn som fikk fjernet prostata i 2008-09 på grunn av kreft.

- Våre resultater viser at hver fjerde operasjon for prostatakreft resulterte i ufullstendig fjerning av svulstvev. Operasjonsteknikken i seg selv - robotteknikk eller åpen teknikk kunne ikke sammenliknes fordi kirurgene som opererte med robot utførte flere prostatakreftoperasjoner årlig enn de som brukte åpen teknikk. Risikoen for ufullstendig fjerning av svulstvev økte hvis kirurgen foretok under 20 prostatakreftoperasjoner årlig - og ved aggressiv kreft, sier Steinsvik.

- Før operasjonen var én av tre pasienter impotent, ett år etterpå var hele fire av fem impotente. Risikoen for at impotensen skulle bli et stort problem for pasienten var størst for menn som hadde et aktivt seksualliv før operasjonen. To av fem pasienter fikk urinlekkasjeproblemer etter operasjonen, sier han.

- Pasientene må få informasjon om individuell risiko for bivirkninger før de gjennomgår operasjon. Det er også viktig at informasjon om bivirkninger hentes direkte fra pasienten, da leger ofte undervurderer problemene.

anne.forus@hotmail.com

Tidsskriftet

\section{Anne Forus}

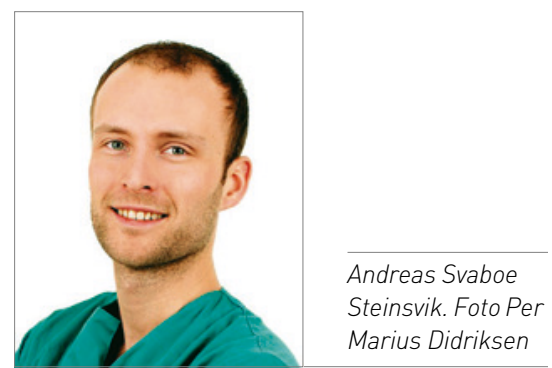

Disputas

Andreas Svaboe Steinsvik disputerte for ph.d.-graden ved Universitetet i Oslo 9.1. 2013 Tittelen på avhandlingen var Outcomes after curative treatment of prostate cancer - adverse effects and surgical margins.

\section{Bagasje må sikres bedre i bil}

\section{Presis informasjon fra skadestedet er nødvendig for å kunne forebygge trafikkulykker og personskader.}

I en ny doktorgrad viser Trine Staff at alvorlighetsgraden av personskade ved bilulykker er assosiert med dårlig fysiologisk status hos pasienten på skadestedet, kvinnelig kjønn, økende alder, førerposisjon i bilen, høy fart og stor vektforskjell mellom de kolliderende bilene. Videre vil tung usikret bagasje ofte treffe og forskyve bilsetene og kunne føre til alvorlige skader i hode, bryst, mage og bekken. De som var truffet direkte av usikrede gjenstander i kollisjonsøyeblikket, hadde alvorlige skader i hode, nakke og bryst.

Over en periode på 14 måneder i 2004-06 ble 190 trafikkulykker med 618 personer involvert inkludert i studien. 353 ble skadet - av disse døde 61 , de aller fleste på skadestedet. Svært mange av de døde ble ikke obdusert.

- Dette betyr et vesentlig informasjonstap om de mest alvorlige skadene. Kunnskap om ulykkesforholdene er svært viktig for å kunne iverksette målrettede trafikkforebyggende tiltak og kampanjer, forteller Staff, som har vært doktorgradsstipendiat ved Norsk Luft- ambulanse. - Innføring av nasjonale medisinske dokumentasjonsprosedyrer, opplæring i disse og bedre dokumentasjonsverktøy i ambulansetjenesten kunne gitt langt mer utfyllende data fra prehospitalt arbeid, sier hun.

- Presis informasjon fra skadested og pasienttransport er sentralt for forskningsformål, men det er også avgjørende for at rett pasient blir prioritert til riktig behandlingsnivå, for å sette legene bedre i stand til raskt å diagnostisere pasientene og for at riktige ressurser raskt blir mobilisert, fortsetter hun.

- Det er behov for trafikkforebyggende kampanjer der man advarer spesifikt mot usikrede gjenstander og tung bagasje i bilen. Utvikling av bakseter som er mer motstandsdyktige mot tung bagasje ser dessuten ut til å være et viktig satsingsfelt for bilindustrien,

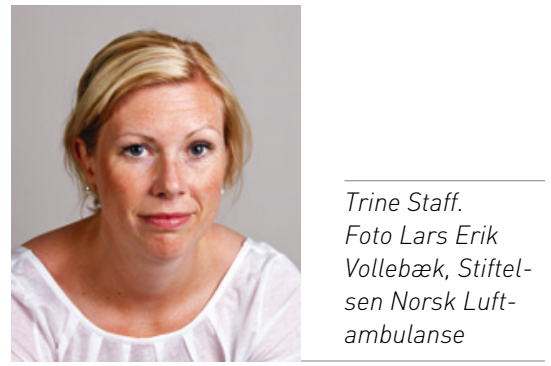

Disputas

Trine Staff disputerte for ph.d.-graden ved Universitetet i Oslo 20.12. 2012. Tittelen på avhandlingen er Real-life motor vehicle accidents - studies on pre-hospital documentation and field triage predictors of injury severity. 